\title{
Albrecht Classen
}

Early History of the Southwest Through the Eyes of German-Speaking Jesuit

Missionaries. A Transcultural Experience in the Eighteenth Century. Lanham,

Boulder, New York, Toronto, Plymouth, UK: Lexington Books, 2013. Pp. xi + 216. Hb, $\$ 60.00$.

Jesuit missionaries to northwest Mexico during the Spanish colonial period included a surprising number of German speakers. The Spanish crown was uneasy with the presence of Germans and other foreigners at the outset of the period, but the demand for Jesuits so outstripped supply that it became prudent to admit non-Spaniards to the evangelizing efforts. Several of the Germanspeakers provided detailed descriptions of the geography of Sonora and the culture of the Indians, far more so than most Spanish priests. In this volume Albrecht Classen underscores the contributions of these German-speaking Jesuits, including priests "from all over the German empire, including [...] Slovakia, Moravia, Poland, Bohemia, Austria, Switzerland, Slovenia, Italy, Bavaria, Alsace, and Franconia" (45).

He provides synopses of the missionary life of Eusebio Kino, the geographical and ethnological observations of Ignaz Pfefferkorn, the ruminations and travels of Joseph Och, and the letters of Phillip Segesser. He devotes a chapter to other prominent German Jesuits, apparently derived entirely or nearly so from the published writings of the contemporary German Jesuit historian Bernd Hausberger. Some of those discussed never visited Sonora. He also devotes considerable space to a discussion of the Jesuits' agenda and the Society's expulsion from the Americas. In the case of the chapters on Kino, Pfefferkorn, and Och, the book adds no information not readily available to the public. Classen seems to rely heavily on Herbert Bolton and Charles Polzer for his discussion of Kino. Pfefferkorn's Sonora: A description of the Province has been available since its English publication in 1989. Och's travel reports have been accessible in English since 1965. I will discuss the letters from Segesser below.

In terms of German Jesuits, I was disappointed to find no mention of the activist Bohemian Jesuit Daniel Januske who in the early eighteenth century clashed with ranchers and secular authorities over treatment of Indians, or of Jacob Sedelmayr, a Bavarian who was an intrepid and indefatigable explorer and advocate for Indians. Classen discusses Alexander Rapicani briefly, but neglects to mention his overseeing of the building of Sonora's finest mission church, that of Batuc, and the importation of European masons to cut the rock for its construction. I find Classen's description of the Jesuits and their 
expulsion duplicative of others' efforts, excessively long, and superficial. I find no mention of the role in the expulsion played by the royal inspector, José de Gálvez, or the crown's efforts to increase revenues by opening up the northwest of Mexico to private ownership. Classen does not mention the writings of Luis Navarro-García or Susan Deeds whose works are basic to an understanding of the Jesuit period in northwest Mexico. Classen on at least four occasions dangles the modifier "tragically" to describe the expulsion of the Jesuits. "Tragically $[\ldots]$ the Jesuits were ultimately forced to leave and their entire missionary network was destroyed" (5). The expulsion may have been tragic for Jesuits, but Indians probably found it liberating, settlers found it useful, and Franciscans found in it an excellent opportunity, not a tragedy.

I found several egregious errors in the book. In his foreword, Classen announces that "the first Europeans arrived in northern Mexico at the end of the seventeenth century" (ix). This ignores all previous expeditions and the fact that Jesuits first arrived in Sonora during the early 1620 s and by $165^{\circ}$ had established nearly all missions of the Opatería. Classen appears to confuse the Arizona city of Casa Grande with the Hohokam archaeological site of Casa Grande, located on the Gila River Indian Reservation (2 and 5) He labels a "desert fruit" described by Segesser as "Indian fig," considering it the fruit of the domestic prickly pear Opuntia ficus-indica (184). The fruit thus described is the pitaya, the fruit of the pitayo, the organ pipe cactus, Stenocereus thurberi. (Segesser goes on to describe prickly pears, but not the domestic variety, Opuntia ficus-indica.) On page 79 Classen states that "[Adam] Gilg never saw Sonora himself," in spite of his earlier description of Gilg's travels in Sonora. More errors abound. These suggest that the book was rushed to publication.

Finally, I must comment briefly on Classen's chapter concerning the letters from the Swiss Jesuit Philipp Segesser. In the 196os, Raymond H. Thompson, director of the Arizona State Museum at the University of Arizona, undertook to facilitate a long-term project to obtain access to and translate Father Segesser's letters. Several noted Jesuit scholars, including Bernard Fontana, Dan Matson, and Charles Polzer were actively involved in the project with strong support from descendants of Father Segesser's family. The project involved extensive photographing and microphotographing of original documents and Indian hide paintings as well as translation of the letters. In 1996, Albrecht Classen became involved in the project at the invitation of Thompson. More than decade later, Classen withdrew from the collaborative project and published his own work, while casting doubt upon the scholarly authenticity of the work of Thompson and his collaborators. Thompson's completed 
work, in press at the University of New Mexico Press, will appear in early 2014. Critical readers will then have an opportunity to judge the scholarly merits of the two publications. In short, I cannot recommend this volume as a scholarly addition to understanding the work of Jesuits in northwest Mexico.

\author{
David Yetman \\ University of Arizona \\ dyetman@email.arizona.edu
}

